\title{
The Establishment of IL-2 Producing Cells by Genetic Engineering
}

\author{
Reiko Sasada, Haruo Onda and Koichi Igarashi
}

Biotechnology Laboratories, Central Research Division, Takeda Chemical Industries, Ltd., Osaka 532, Japan

\begin{abstract}
Expression plasmids containing human interleukin-2(IL-2) cDNA under the control of viral promoters (SV40 early region, MuLV LTR, HTLV-I LTR, and ASV(Y73) LTR) were introduced into TK- mouse $L$ cells and human FL cells to establish IL-2 producing cells. The highest levels of IL-2 producing clones were obtained in $\mathrm{TK}^{+}$mouse $\mathrm{L}$ cells transformed with a recombinant plasmid having MuLV LTR as a promoter, whereas transformed cells of human FL cells (G418r) were revealed to produce IL-2 at the highest level when the cells were transfected with a plasmid containing HTLV LTR as a promoter. These results suggest that these promoter/enhancer regions possess different cell specificities in gene expression. To obtain higher levels of IL-2 production using gene amplification, the hybrid plasmids containing the hamster DHFR and human IL-2 genes were constructed and transfected into DHFR - CHO cells. DHFR + colonies produced IL- 2 at about the same level as that produced by $\mathrm{TK}^{+} \mathrm{L}$ cells transformed with the recombinants containing MuLV LTR. Selection of methotrexate-resistant cells resulted in a 5- to 30-fold increase of IL-2 production. These cells produced IL-2 stably for at least 3 months, even in the absence of methotrexate.
\end{abstract}

Studies on and the use of the physiologically active proteins are, in many cases, hampered by the limited amounts of the purified substance. Recombinant DNA technology is now widely used to produce such proteins, for instance, interferons, lymphokines and growth factors, in prokaryotes in high amounts. However, many of these secretary proteins from natural sources receive post-transcriptional modifications, such as glycosylation, which are not performed by prokaryotes. Several systems $(7,38)$ have been developed to express cloned DNA in mammalian cells, in which the resulting proteins are believed to be glycosylated and secreted. To obtain established cell lines that express the introduced foreign genes at high levels, the most suitable promoter-vector system has to be used for each host cell type. Furthermore, the gene amplification procedures have been known to be rather effective for obtaining a high level of gene expression $(12,16,25,31)$.

Here, we report the comparative studies on the suitable promoters for the expression of CDNA of human IL-2, a lymphokine which plays an essential role in immunoregulatory networks $(3,28)$ in mouse or human cells, and the establishment of cell lines which constitutively synthesize and secrete human IL-2. We also describe the expression of this gene in $\mathrm{CHO}$ cells by using two kinds of amplifiable vectors. 


\section{MATERIALS AND METHODS}

Cell culture. Mouse L TK- cells (obtained from Dr. Y. Okada), and human FL cells (purchased from Flow Labs.) were cultured in Eagle's minimal essential medium (MEM, Nissui Seiyaku Co.) supplemented with $10 \%$ fetal calf serum (FCS, Microbiological Associates). $\mathrm{TK}^{+} \mathrm{L}$ cells were selected in the same medium supplemented with $0.1 \mathrm{mM}$ hypoxanthin $/ 0.4 \mu \mathrm{M}$ aminopterin $/ 0.16 \mathrm{mM}$ thymidine $/ 3 \mu \mathrm{M}$ glycine (HAT medium) (23). FL cells resistant to G418 (Gibco Labs.) were selected in the presence of $800 \mu \mathrm{g} / \mathrm{ml} \mathrm{G} 418$ (4). DHFR- CHO cells (36) (obtained through Dr. P. Berg) were cultured in Ham's F12 medium (Flow Labs.) supplemented with $5 \%$ FCS. DHFR + CHO cells were selected in Dulbecco's modified MEM (DME, Flow Labs.) supplemented with dialyzed FCS and $35 \mu \mathrm{g} / \mathrm{ml}$ proline. Several transformed clones of DHFR + CHO cells were propagated in selective medium and exposed to stepwise increasing concentrations of 0.01 to $100 \mu \mathrm{M}$ methotrexate (MTX, Sigma Chemical Co.). An IL-2 dependent mouse NK cell line, NKC3 (34) (provided by Dr. K. Kumagai), was maintained in a RPMI-1640 medium (Flow Labs.) supplemented with $20 \%$ FCS and about 1 unit $/ \mathrm{ml}$ of human IL-2 (26).

Recombinant DNAs and construction of recombinant plasmids. The transformation of E. coli DH1 (11); preparation of plasmid or phage DNA, and digestion with restriction enzymes; separation of DNA fragments; and DNA modification and ligation were carried out by standard procedures as described in Maniatis et al. (24).

A plasmid pTB106, a pcD vector (27) containing human IL-2 cDNA, was constructed by ligating three fragments together: the large $2.5 \mathrm{~kb}$ HindIII-BamHI fragment from pcDV1 containing the pBR322 ori, ampicillin-resistant gene and the SV40 late-region polyadenylylation signal; the $0.5 \mathrm{~kb}$ HindIII-PstI fragment from pP11 containing the SV40 early-region promoter and late-region introns (pP11 and pcDV1 were obtained from Drs. H. Okayama and P. Berg.); and the $0.56 \mathrm{~kb}$ PstI-StuI fragment from a human IL-2 cDNA clone, pILOT135-8 (32), containing the entire 462 bp IL-2 coding sequence flanked by $64 \mathrm{bp}$ (17 bp dG-dC stretch) of 5' and $33 \mathrm{bp}$ of 3' untranslated regions (Fig. 1). DNA fragments
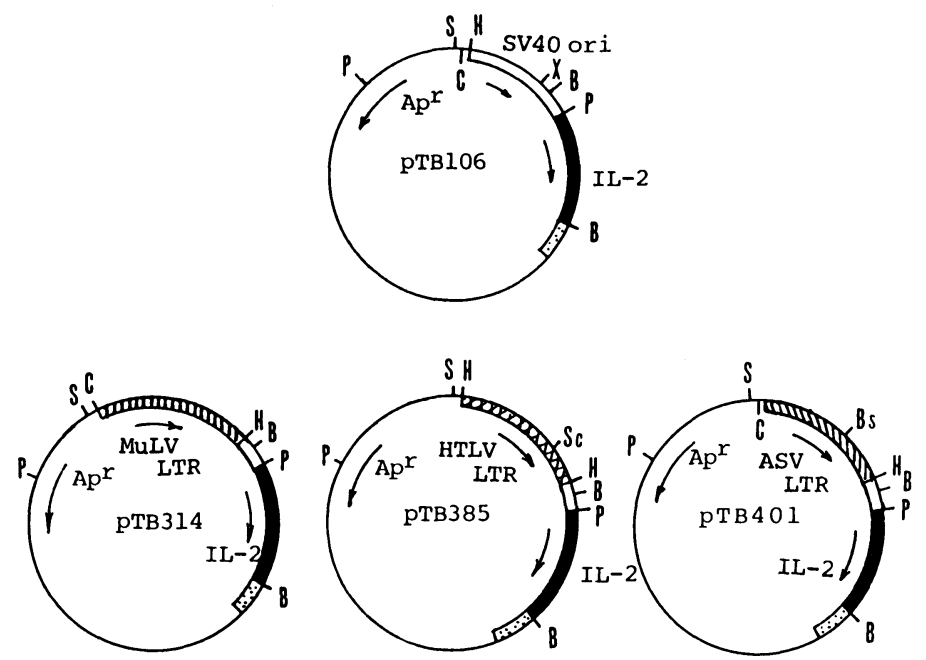

Fig. 1. Structure of recombinant plasmids, pTB106, pTB314, pTB385 and pTB401, containing various promoters and human IL-2 cDNA. See Materials AND Methods for details. B, BamHI; C, ClaI; E, EcoRI; H, HindIII; P, PstI; S, SalI; X, XhoI; Bg, BglII; Bs, BstXI; Sc, SacI. 


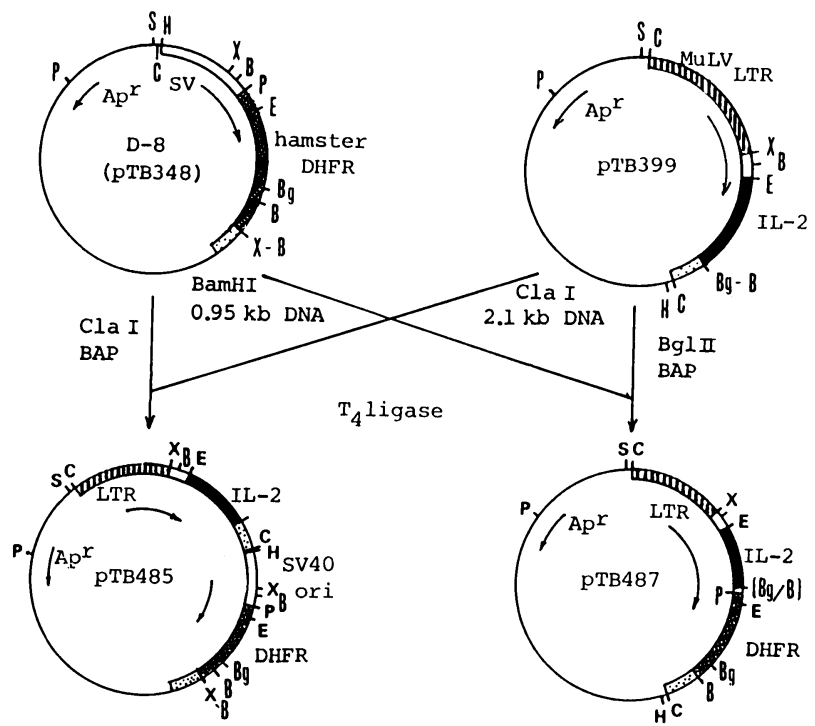

Fig. 2. Construction of two recombinant plasmids containing the DHFR and IL-2 genes pTB485 and pTB487.

containing LTR sequences of retroviruses: A-MuLV, HTLV, and ASV-Y73; were introduced, respectively, into pTB106 at the unique HindIII site upstream of the SV40 promoter, followed by substitution of the promoter region by LTRs. Three recombinant plasmids: pTB314 containing A-MuLV LTR, pTB385 containing HTLV LTR, and pTB401 containing ASV-Y73 sequences; as the promoter for expressing IL-2 cDNA, were constructed (Fig. 1). The DNA fragments of the LTR region were as follows: the $1.15 \mathrm{~kb}$ ClaI-PstI fragment from plasmid pYJ1, a recombinant plasmid recloned A-MuLV cDNA from lambda Ab3 (8) into pBR322 (obtained from Dr. Baltimore); the $0.75 \mathrm{~kb}$ Rsal fragment from a cDNA clone of HTLV, pATLV421 (20) (obtained from Dr. M. Hatanaka); and the $0.6 \mathrm{~kb}$ DNA fragment containing one LTR region prepared from the $0.9 \mathrm{~kb}$ HindIII-SacI fragment (containing a tandem repeat of LTR), which was isolated from lambda Y73-11A (19) containing the entire ASV-Y73 provirus DNA (obtained from Dr. M. Yoshida).

The construction of pTB485 and pTB487 is shown in Fig. 2. Plasmid D-8 (pTB348), containing about $1.1 \mathrm{~kb}$ of hamster DHFR cDNA, which can be expressed in DHFR-CHO cells (unpublished results), was isolated by rescuing the DHFR gene from DHFR+ CHO cells, which had been transformed with a cDNA library of hamster cells prepared by the method of Okayama and Berg (27). Plasmid pTB399 was an IL-2 expression vector which was constructed from pTB314 with some modification of restriction sites. These two plasmids were recombined, and two different IL-2-DHFR hybrid plasmids pTB485 and pTB487 were constructed.

Plasmid pTK61 was derived from pTK (obtained from Dr. L.W. Enquist (6) ), by inserting a $2.0 \mathrm{~kb}$ PvuII fragment containing the entire HSV thymidine kinase (TK) gene into the PvuII site of pBR322. Plasmid pTB6 was constructed from neomycin-resistant genes derived from pKml (1) (obtained through Dr. P. Berg) and TK genes. The structure of pTB6 was identical to pAG60 (4).

Cell transformation and selection. Transfections were performed by the calcium phosphate coprecipitation procedure $(10,38)$. About $7 \times 10^{5}$ mouse $\mathrm{TK}^{-} \mathrm{L}$ cells or human FL 
cells per $6 \mathrm{~cm}$ Falcon dish were transfected with $10 \mu \mathrm{g}$ of expression vector and $0.2 \mu \mathrm{g}$ of plasmid containing selective marker genes. DHFR- CHO cells were transfected with 1 to $5 \mu \mathrm{g}$ of hybrid plasmid and $5 \mu \mathrm{g}$ of salmon sperm DNA as a carrier. After being grown for 2 days in a nonselective medium, the cells were trypsinized and seeded into 96 well microplates with the selective medium. The cells were maintained and fed every 3 to 4 days. After 3 weeks, when a colony appeared in one well of the microplates, the colonies were then cloned and transferred to Limbro dishes.

Assay for IL-2 activity. IL-2 activity was determined by the colorimetric proliferation assay using IL-2 dependent NKC3 cells, described by Tada et al. (35). The units of IL-2 were calculated by determining the dilution of the factor required to give $50 \%$ of the maximal stimulation, where 1 unit is defined as the amount of IL-2 in a standard sample which is the culture supernatant of human peripheral blood lymphocytes stimulated by ConA and TPA, as described elsewhere in detail (13).

Southern hybridization analysis. High molecular weight cellular DNA was isolated as described by Blin and Stafford (2). DNA (10-15 $\mu \mathrm{g}$ ) was digested with the indicated enzymes, electrophoresed on a 0.8 to $1.5 \%$ agarose gel, transferred to nitrocellulose filters (Millipore Inc.), and hybridized to a ${ }^{32}$ P-labeled human IL-2 cDNA probe (36). The labeled probe was the $0.56 \mathrm{~kb}$ PstI-BamHI fragment from pTB106 prepared by nick translation (29).

$S D S$-polyacrylamide gel analysis of ${ }^{35} S$-methionine labeled $I L-2$ produced by transformed cells. Confluent monolayers of transformed cells in $3.5 \mathrm{~cm}$ dishes were labeled for $24 \mathrm{~h}$ in methionine-free MEM supplemented with $5 \%$ dialyzed FCS and $50 \mu \mathrm{Ci}$ of $\left[{ }^{35} \mathrm{~S}\right]-$ methionine $(1,000 \mathrm{Ci} / \mathrm{mmol}$, Amersham). Immunoprecipitations were performed according to Kessler (17), using $0.2 \mathrm{ml}$ of culture medium and $10 \mu \mathrm{l}$ of rabbit anti-human IL-2 antiserum. Electrophoresis on $17.5 \%$ SDS-polyacrylamide gel was carried out according to Laemmli (21), and labeled proteins of immunoprecipitates were detected by autoradiograph after treatment by fluorography.

\section{RESULTS}

Transformation of $\mathrm{TK}^{-}$mouse $L$ cells with expression plasmids. $\mathrm{TK}^{-}$mouse $\mathrm{L}$ cells were transfected with the recombinant plasmids using a 50 -fold excess of IL-2

(A)

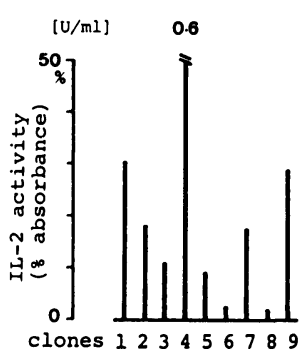

(B)

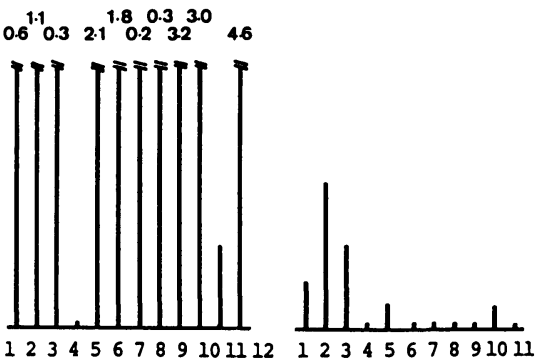

(D)

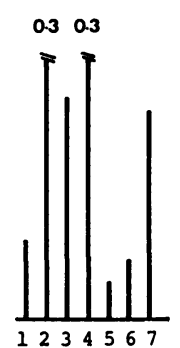

Fig. 3. IL-2 activity in culture medium produced by clones of mouse $\mathrm{L} \mathrm{TK}^{+}$transformants. Cells were grown to reach about $80 \%$ confluent in 24 well plates and the medium was changed to $1 \mathrm{ml}$ of fresh MEM containing 10\% FCS per well. After cultivation for $48 \mathrm{~h}$, the culture supernatant was collected and assayed for IL-2 activity. IL-2 activity was measured by stimulating the growth of NKC3 cells as described in MATERIALS AND METHODS. Each bar indicates IL-2 activity of the culture supernatant of each clone ( $2^{2}$ dilution) by $\%$ absorbance of the maximum stimulation. When over $50 \%$ stimulation was observed, units of IL-2 were calculated, and are shown above each bar. A) LIL106, B) L-IL314, C) L-IL401, D) L-IL385. 
(A)

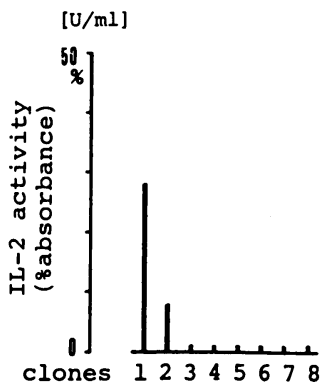

(B)

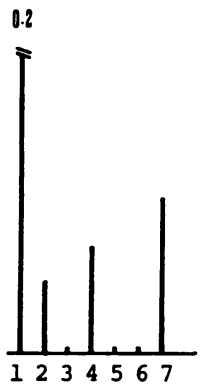

(C)

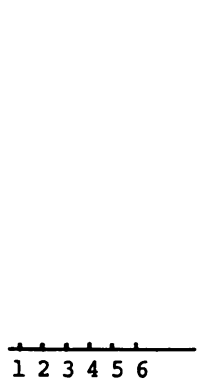

(D)

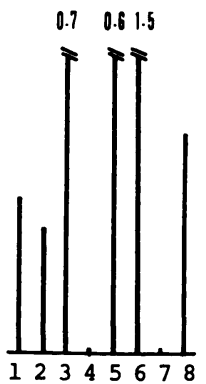

Fig. 4. IL-2 activity in culture medium produced by clones of human FL cell transformants $\left(G 418^{r}\right)$. Conditions for measuring IL-2 activity in the culture medium were as described in the legend to Fig. 3. A) FL-IL106, B) FL-IL314, C) FL-IL401, D) FL-IL385.

expression plasmids (Fig. 1) over the pTK61 carrying the cloned HSV TK gene (38). $\mathrm{TK}^{+}$clones (10 to 20 per $10^{6}$ transfected cells) were obtained after two weeks. Culture supernatants of individual transformed clones were collected $48 \mathrm{~h}$ after the cells were $80 \%$ confluent (about $10^{6}$ cells $/ \mathrm{ml}$ ) and were assayed for human IL-2 activity.

Figure 3 shows the activity of IL- 2 produced by $\mathrm{TK}^{+} \mathrm{L}$ cell individual clones transformed with IL-2 expression plasmids directed by various promoters. Among 9 transformed clones obtained with pTB106 directed by the SV40 early-region promoter (L-IL106), IL-2 activity was detected in the culture medium of 7 clones. Clone 4 (L-IL106-4) showed the highest production of IL-2 (0.6 units $/ \mathrm{ml})$, but most clones produced 0.01 to 0.1 units $/ \mathrm{ml}$ of IL-2. In comparison, almost all clones transformed with pTB314 containing MuLV LTR as a promoter (L-IL314) produced over

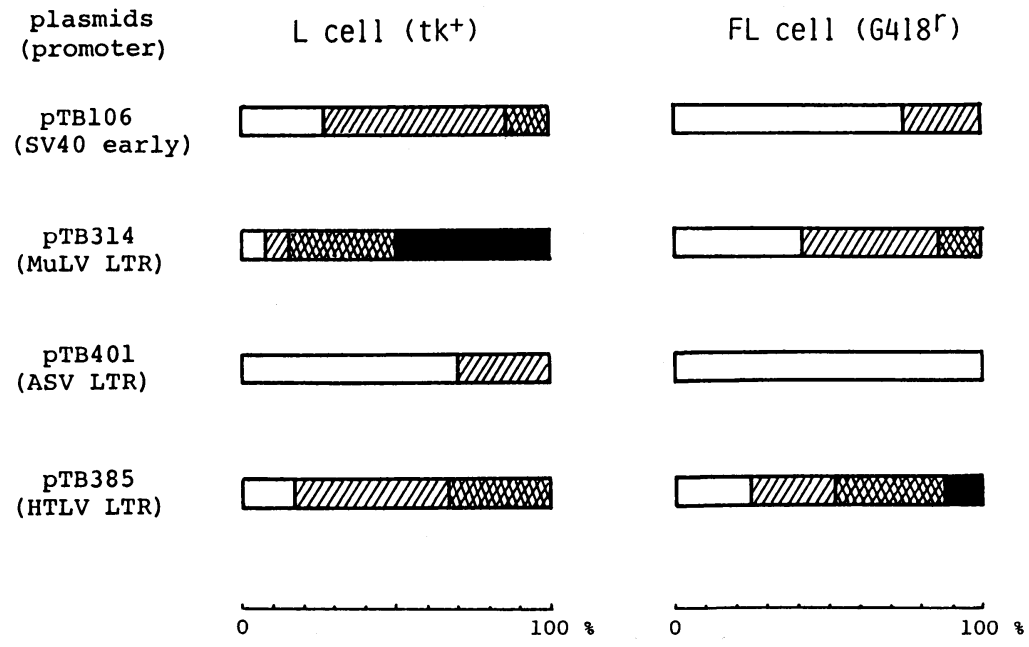

Fig. 5. Effects of various promoters on IL-2 production in mouse L cells and human FL cells. IL-2 producing clones represented in Fig. 3 and Fig. 4 were distributed based on the IL-2 productivity. $\square<0.01$ units $/ \mathrm{ml}$, WIIA 0.01 to 0.1 units $/ \mathrm{ml}$, 0.1 to $1.0 \mathrm{units} / \mathrm{ml}$, and $\square>1.0 \mathrm{units} / \mathrm{ml}$ of IL-2 activity. 
0.2 units $/ \mathrm{ml}$ of IL-2 in the culture medium; the highest activity, 4.6 units/ml, was detected in clone 12 (L-IL314-12). Of 7 clones transformed with pTB385, having HTLV LTR as a promoter, 6 produced from 0.01 to 0.3 units $/ \mathrm{ml}$ of IL-2, the same level as that observed in L-IL106 transformed cells. Transformants with pTB401, having ASV-Y73 LTR as a promoter, produced only low levels of IL-2. L cells transformed with pILOT135-8, a plasmid containing IL-2 cDNA without promoter region, did not produce IL-2 $(<0.01 \mathrm{unit} / \mathrm{ml}$, background level, data not shown).

Transformation of human FL cells with expression plasmids. The expression plasmids having the IL-2 gene directed by various promoters were also introduced into human FL cells with plasmid pTB6 carrying the G418 resistant gene (4). Transformed clones were available after cultivation for 3 weeks in a selective medium containing $800 \mu \mathrm{g} / \mathrm{ml} \mathrm{G} 418$ ( 3 to 6 clones per $10^{6}$ transfected cells). In 8 clones tested, 6 transformed with pTB385, the plasmid containing HTLV LTR region as a promoter produced IL-2 in the culture medium. The IL-2 activity of 3 of the 6 clones was above 0.6 units $/ \mathrm{ml}$ and one, the FL-IL385-6 cells, produced 1.5 units $/ \mathrm{ml}$. On the other hand, among 7 clones transformed with pTB314 (MuLV LTR), 4 produced 0.2 units $/ \mathrm{ml}$
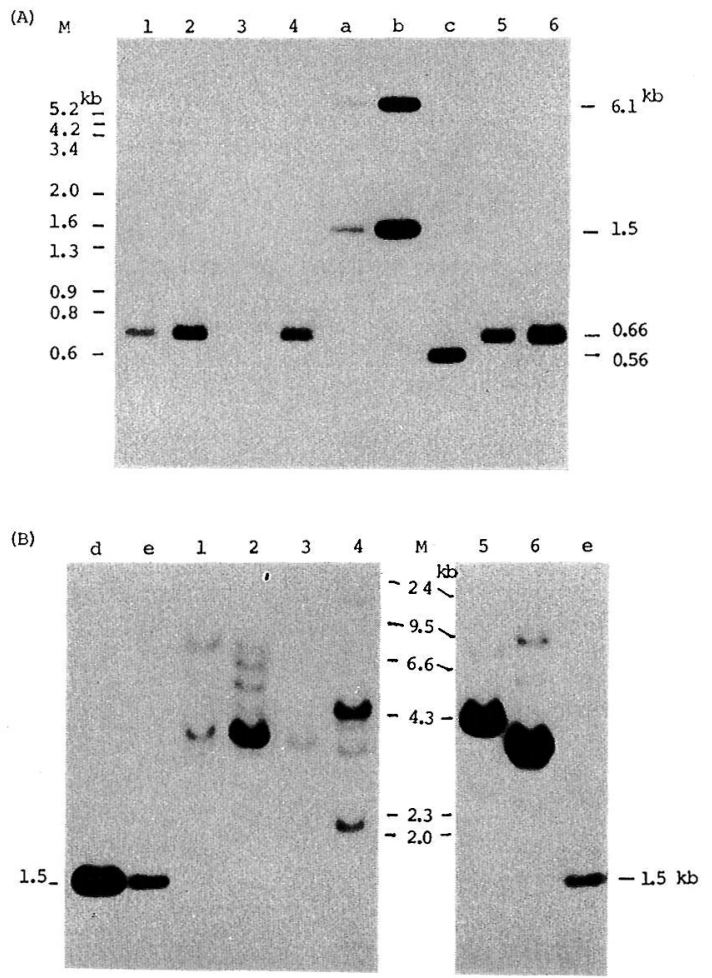

Fig. 6. Southern hybridizations of cellular DNA from several IL-2 producing clones of mouse $\mathrm{L}$ cell transformants. High molecular weight cellular DNA $(10 \mu \mathrm{g}$ (A) or $15 \mu \mathrm{g}$ (B)) was digested with BamH I (A) or HindIII (B), electrophoresed on $1.5 \%$ (A) or $0.8 \%$ (B) agarose gel, blotted on nitrocellulose filters, and hybridized to a nick-translated human IL-2 cDNA probe. Lane 1, L-IL106-1; 2, L-IL106-4; 3, L-IL314-3; 4, L-IL314-12; 5, L-IL401-2; 6, L-IL385-4. Lanes a and b, pTB485 digested with HindIII and EcoRI, respectively, were applied simultaneously (20 pg each (a) and 200 pg each (b) ); lane c, $10 \mathrm{pg}$ of $0.56 \mathrm{~kb}$ PstI-BamHI DNA fragment from pTB106; lanes d and e, pTE485 digested with EcoRI (200 pg (d) and 40 pg (e)). 
of activity, at most. In 2 of 8 clones of transformants with pTB106 (SV40 early-region promoter), IL-2 activity of up to 0.1 units $/ \mathrm{ml}$ was detected; no activity was detected in any of the transformants with pTB401 (ASV-Y73 LTR) (Fig. 4). The results on the IL-2 production of various $L$ cell transformed clones in comparison with that of human FL cells are summarized in Fig. 5. In a preliminary experiment, 4 recombinant plasmids, pTB106, pTB314, pTB385 and pTB401, were introduced into DHFRhamster CHO cells with the expression plasmid of DHFR cDNA, pTB348. The $\mathrm{DHFR}^{+}$transformants which appeared on one dish (10-50 colonies) were mixed and cultured. Much more IL-2 production (about 0.3 to 1 units $/ \mathrm{ml}$ ) was observed in the case of pTB314 (MuLV LTR) and pTB385 (HTLV LTR) than that with pTB106 $(0.1$ to 0.2 units $/ \mathrm{ml})$ or pTB401 $(<0.05$ units $/ \mathrm{ml})$. Hence, the promoter activity of MuLV LTR or HTLV LTR seems to be stronger than that of SV40 early-region promoter or ASV LTR in CHO cells.

Southern blotting analyses of $L$ cell transformants. Cellular DNAs of $\mathrm{L}$ cell transformants were digested with HindIII or BamHI, and the IL-2 genes were analyzed using the Southern blotting with ${ }^{32} \mathrm{P}$-labeled IL-2 cDNA as a probe (Fig. 6). The hybridization patterns and visual concentration of autoradiographs indicated that most $\mathrm{L}$ cell transformants had multiple insertions of IL-2 cDNA accompanied by rearrangements. In addition, there seems to be a correlation between the copy number and ability for IL-2 production in the transformants: among the transformants with the same recombinant plasmids, the more copies of IL-2 cDNA there were, the greater the IL-2 activity. In contrast, the clone, L-IL314-12, transformed with pTB314 (MuLV LTR) and shown to have the highest level of IL-2 production, had fewer copies than the transformants with pTB106 (SV40 early), pTB385 (HTLV LTR-IL-2), and pTB401 (ASV-Y73 LTR). These results suggest that IL-2 production in the transformants depends on promoter activity and copy number, at least.

Transformation of $\mathrm{CHO}$ cells with two amplifiable plasmids. It has been reported that a high level of gene expression was observed with amplifiable vectors; for example, MTX has been used as a means to amplify the newly introduced genes with the DHFR gene $(12,25)$. Figure 2 illustrates the construction of two kinds of DHFR gene-linked hybrid plasmids for expressing human IL-2 cDNA in CHO cells. One of them, pTB485, carries two complete transcription units in tandem arrangement, that is, IL-2 gene expression directed by MuLV LTR and DHFR gene expression

TABLE 1. IL-2 PRODUCTION BY TRANSFORMED AND MTX ${ }^{\mathrm{r}}$ CHO CELLS.

\begin{tabular}{|c|c|c|c|c|}
\hline Plasmids & Transformants & $\begin{array}{l}\text { Parental } \\
\text { cells }\end{array}$ & $\begin{array}{c}\text { IL-2 (units } / \mathrm{ml} \text { ) } \\
\text { MTX } 10 \mu \mathrm{M}^{\mathrm{r}} \\
\text { cells }\end{array}$ & Ratio \\
\hline \multirow[t]{4}{*}{ pTB485 } & C-IL485-4 & 2.0 & 59.0 & 30 \\
\hline & C-IL485-5 & 0.34 & 4.1 & 12 \\
\hline & C-IL485-6 & 1.0 & 5.5 & 5.5 \\
\hline & C-IL485-7 & 0.4 & 12.8 & 32 \\
\hline \multirow[t]{4}{*}{ pTB487 } & C-IL487-2 & 0.35 & 2.1 & 6 \\
\hline & C-IL487-5 & 0.5 & 2.7 & 5.5 \\
\hline & C-IL487-8 & 3.0 & 12.8 & 4.3 \\
\hline & C-IL487-10 & 10.5 & 20.3 & 2 \\
\hline
\end{tabular}

IL-2 activity in the culture medium was assayed as described in the legend of Fig. 3, except DME supplemented with $5 \%$ FCS and $35 \mu \mathrm{g} / \mathrm{ml}$ proline was used. 
directed by the SV40 early region promoter, whereas pTB487 has the structure of a polycistronic-type vector, in which both IL-2 cDNA and DHFR cDNA are under the control of a promoter, MuLV LTR.

DHFR - CHO cells were transfected with these plasmids, and the cells were selected by virtue of their $\mathrm{DHFR}^{+}$phenotype. The frequencies of transformation were 1 to $2 \times 10^{-4}$ per cell with pTB485, and 2 to $5 \times 10^{-6}$ per cell with pTB487. The IL-2 activities in the culture mediums of 9 individual clones were assayed. All the transformants with pTB485 (C-IL485) produced IL-2 at a level of 0.1 to 2.5 units $/ \mathrm{ml}$. Of 9 clones with pTB487, 8 produced IL-2; one, C-IL487-10, produced 10 units $/ \mathrm{ml}$. The levels of IL-2 production in these $\mathrm{CHO}$ transformants were similar to those in $\mathrm{TK}^{+} \mathrm{L}$ cell transformants obtained by cotransformation with pTB314 (MuLV LTR).

Amplification of IL-2 gene. Eight clones from CHO transformants, 4 with pTB485 and 4 with pTB487, were chosen for the attempts to select MTX-resistant cells. These parental clones were first exposed to $10 \mathrm{nM}$ MTX, and then to increasing concentrations of MTX up to $10 \mu \mathrm{M}$ by a stepwise procedure. For example, C-IL485-4 cells could grow to confluency in $10 \mathrm{nM}$ and $100 \mathrm{nM}$ MTX, but only a few colonies per $10^{5}$ parental cells were grown in $1 \mu \mathrm{M}$. These resistant colonies were grown to mass culture, then placed in $10 \mu \mathrm{M}$ MTX. Again, a few colonies survived at this concentration and were grown to mass culture.

Table 1 shows the levels of IL-2 production by $10 \mu \mathrm{M}$ MTX-resistant cells and their parental clones. MTX-resistant cells derived from each clone of C-IL485 showed a 5- to 30-fold increase in IL-2 productivity. In particular, MTX-resistant cells from C-IL485-4 produced the highest level of IL-2, 59 units $/ \mathrm{ml}$. In contrast, a small increase of IL-2 production (2- to 6-fold) was observed in MTX-resistant cells from

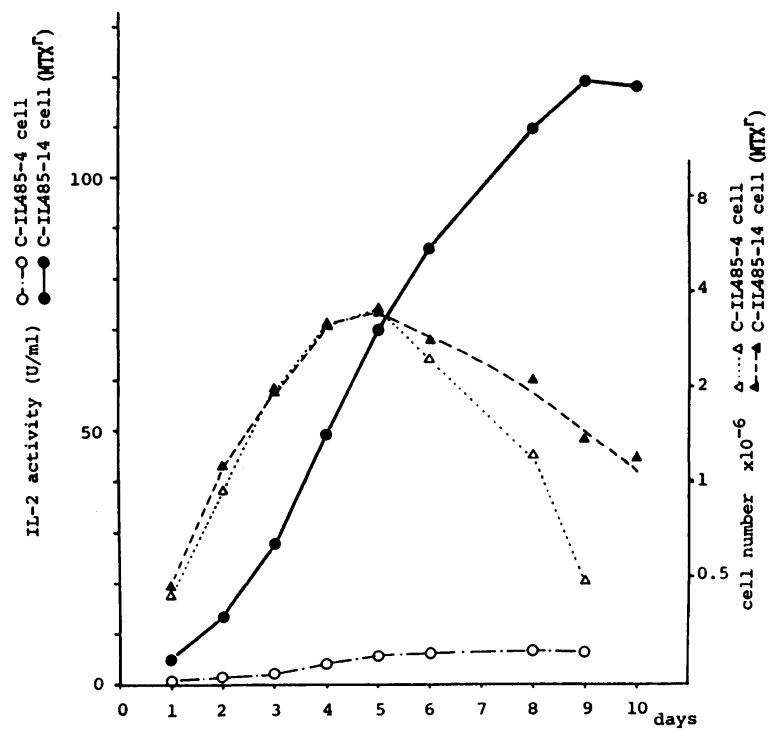

Fig. 7. Production of human IL-2 by C-IL485-4 and C-IL485-14 cells (MTX resistant). Cells were seeded at $2 \times 10^{5}$ cells per $3.5 \mathrm{~cm}$ dish in MTX-free culture medium. After overnight cultivation, cells were fed with $2 \mathrm{ml}$ of fresh medium (day 0 ) and incubated another 9 to 10 days. At the indicated times, IL-2 activity in the medium was determined and cell numbers were counted after removing cells by trypsinization. IL-2 activity, C-IL485-4 ○-- $\bigcirc$, C-IL485-14 @- ; cell numbers, C-IL485-4

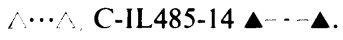


4 clones with pTB487 transfection. Subsequently, $100 \mu \mathrm{M}$ MTX-resistant cells were isolated and assayed for IL-2 production. In most case, however, these cells could not grow well, and no increases of IL-2 production above that of the $10 \mu \mathrm{M}$ MTXresistant cells were observed.

IL-2 activities in the culture mediums (MTX-free) of C-IL485-4 cells and C-IL48514 cells $\left(\mathrm{MTX}^{\mathrm{r}}\right)$ were determined during cell growth. The IL-2 activity in the culture medium increased in parallel with the cell number during the first 5 days (Fig. 7). After the cells became confluent and showed no growth, IL-2 production continued to increase for another 4 days. It reached 119 units/ml in the C-IL485-14 cells; this level was 18 -fold of that in the parental clone, C-IL485-4 cells ( 6 units $/ \mathrm{ml})$. This high production of IL-2 by C-IL485-14 cells continued stably for at least 3 months with serial cell passage in the MTX-free medium.

To examine the state of transfected DNA and the level of gene amplification in these cells, cellular DNA was isolated and analyzed by Southern blotting (37). A signal corresponding to the expected $1.5 \mathrm{~kb}$ fragment was found to be hybridized to the human IL-2 cDNA probe when cellular DNA was cleaved with EcoRI, indicating that the DNA was not rearranged in the coding region of IL-2 and its vicinity. By visual comparison with a DNA standard, we estimated that C-IL485-4 cells (the original DHFR + isolate) contained 1 or 2 copies of the IL-2 gene per haploid genome, and in MTX $^{\mathrm{r}}$ cells, the increase in copy number of IL-2 gene was observed to be from 10- to 15 -fold greater than in the original isolate (data not shown). In a blotting experiment with HindIII-cleaved cellular DNA, a DNA fragment greater than $10 \mathrm{~kb}$ was hybridized to the IL-2 probe, demonstrating that integration of the gene into the cellular DNA had occurred (data not shown).

$S D S$-polyacrylamide gel analysis of $I L-2$ produced by $C H O$ transformants. To investigate the IL-2 produced by the C-IL485-14 cells, these cells were incubated in

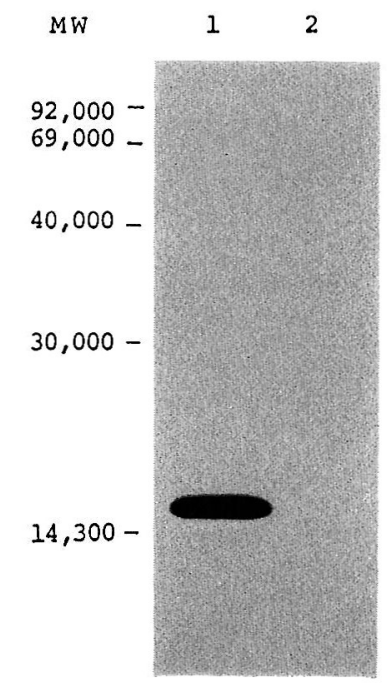

Fig. 8. SDS-polyacrylamide gel electrophoresis of ${ }^{35}$ S-labeled IL-2 secreted by transformed CHO cells. C-IL485-14 or DHFR- CHO cells were labeled with [ $\left.{ }^{35} \mathrm{~S}\right]$ methionine and the culture medium was immunoprecipitated with rabbit anti-human IL-2 serum. Samples were electrophoresed on a $17.5 \%$ SDS-polyacrylamide gel, and radioactive proteins were detected by fluorography. Lane 1 , C-IL485-14 cells and lane 2, CHO cells. 
the presence of $\left.{ }^{[35} \mathrm{S}\right]$ methionine, and the labeled proteins in the medium were analyzed on SDS-polyacrylamide gel electrophoresis using immunoprecipitation against anti-human IL-2 serum. Two bands at the position corresponding to MW of $14 \mathrm{Kd}$ (minor band) and $17 \mathrm{Kd}$ (major band) were observed in the sample from C-IL485-14 cells, but not in the control sample (Fig. 8). The molecular size is different from that calculated from the deduced amino acid sequence (MW $15 \mathrm{Kd}$ ), but is similar to the size of natural human IL-2 produced by peripheral blood lymphocytes (15).

\section{DISCUSSION}

A plasmid pTB106, having the entire IL-2 cDNA under the control of SV40 promoter, and several recombinants which replaced the SV40 promoter of pTB106 with retrovirus LTRs were introduced into mouse or human cells. The cells transformed with these plasmids secreted IL-2 in the culture medium, as expected, thus suggesting that the processing of human IL-2 protein occurred correctly in mammalian cells.

The levels of IL-2 produced and secreted into the culture medium by each transformant were examined, and the effects of promoters on the expression of IL-2 genes were compared. Although it is affected by the copy numbers and the site of integration of the recombinant DNAs, the activity of IL-2 produced by these transformants seemed to reflect the promoter activity when a sufficient number of transformants were tested. As shown in Fig. 5, it is suggested that the relative strengths of promoter activities were: MuLV LTR $\gg$ HTLV LTR, SV40 early promoter $>$ ASV-Y73 LTR, in mouse L cells; and HTLV LTR $>$ MuLV LTR $>$ SV40 early promoter $>$ ASV LTR in human FL cells. In mouse L cells, MuLV LTR showed extremely strong promoter activity, and HTLV LTR and SV40 early promoter showed moderate activities. The high level of expression of IL-2 gene by MuLV LTR was confirmed to some extent in Southern blot analyses of the DNA of mouse L cell transformants. That is, there was no definite correlations between copy numbers of the IL-2 gene and ability for IL-2 production when the levels of IL-2 production were compared among transformants with different plasmids. In FL cells, it is noteworthy that HTLV LTR showed stronger activity than the others, although this LTR is known to have a weak promoter activity without a trans-acting enhancer (33). In contrast, ASV-Y73 LTR showed only weak activity in our experiment, while RSV LTR is reported to have strong promoter activity $(9,14)$; the reason for the difference in a promoter activities between ASV and RSV LTRs is not obvious at present. These results on promoter activities are interesting in view of the species specificity of retroviral LTRs $(9,18,22)$.

To obtain greater expression of the IL-2 gene using a gene amplification procedure, we constructed two recombinants, pTB485 and pTB487. In the transformants with pTB485, the IL-2 and DHFR genes might be regulated by MuLV LTR and the SV40 early promoter, respectively. MuLV LTR showed strong promoter activity in CHO cells, and almost all clones tested produced IL-2 up to 2.5 units $/ \mathrm{ml}$. A dramatic increase of IL-2 activity was observed in 1 to $10 \mu \mathrm{M}$ MTX-resistant cells isolated from these clones. To obtain a maximum increase of IL-2 production, rather higher concentrations of MTX were needed in our experiment than those mentioned in other reports $(12,25)$. This difference may be due to the different promoters used for the DHFR gene. In pTB485, DHFR cDNA is under the control of the SV40 early promoter, but in other reports MMTV LTR or the adenovirus major late promoter, which seems to be a weaker promoter than the SV40 early promoter, was used for the 
DHFR gene.

The transformation frequency with pTB487 was less than one-tenth that with pTB485. The plasmid pTB487 carries IL-2 and DHFR cDNA in a tandem alignment under the control of MuLV LTR as a promoter (polycistronic construction). The low frequency of transformation $\left(\mathrm{DHFR}^{+}\right.$) might be caused by the low transcriptional level of DHFR gene. Among the transformants with pTB487, a high producer clone, C-IL487-10 (10 units $/ \mathrm{ml}$ ), was obtained. But the selection of MTX-resistant cells was not as effective as it was with the transformants with pTB485.

C-IL485-14 cells, a clone of MTX-resistant cells selected from C-IL485-4 cells, produced about 30 -fold more IL-2 than did the original clone. Southern blotting analyses of these clones suggest that the increase seems to be caused by amplification of the DHFR gene accompanied by the IL-2 gene, as reported elsewhere $(12,16,25)$. The IL-2 accumulated in culture fluid of C-IL485-14 cells reached as much as $120 \mathrm{units} / \mathrm{ml}$. This corresponds to 3 to $4 \mu \mathrm{g} / \mathrm{ml}$ of IL-2 protein. The production of IL-2 in this MTX-resistant clone was stable for several months, even if MTX was omitted from the medium.

SDS-polyacrylamide gel electrophoresis of secreted proteins from several $\mathrm{CHO}$ transformants revealed at least two bands with mobilities corresponding to $17 \mathrm{kd}$ and $14 \mathrm{kd}$ after immunoprecipitation with anti-human IL-2 anti-serum. In L and FL transformed cells, similar results were also obtained, except that much more of the $14 \mathrm{kd}$ band was observed (about one-third of the $17 \mathrm{kd}$ band) in L cell transformants (data not shown). The molecular values of the immunoprecipitates coincided well with those of natural human IL-2 produced from peripheral blood lymphocytes (15). Hence, both bands seem to represent the human IL-2 polypeptides processed and glycosylated. Recently, Conradt et al. reported that transformed mouse L cells and $\mathrm{CHO}$ cells, with a plasmid containing human genomic IL-2 gene, secreted IL-2 of glycosylated form (5).

No differences in the biological activities of the glycosylated (natural) and nonglycosylated (recombinant) forms of IL-2 have been observed in vitro $(26,30)$, but no reports of in vivo differences have been published. Now that we have obtained several high-producer cell lines of IL-2, it will be possible to purify glycosylated as well as non-glycosylated IL-2, and to compare their physiological properties and therapeutic values. The application of proper promoter-vector and gene amplification systems in animal cells by using recombinant DNA technology will be able to support the establishment of high-producer cell lines of useful proteins and to contribute to their study and use.

Acknowledgements. We thank Dr. H. Okayama for providing the plasmids pPI1 and pcDV1, Dr. P. Berg for the plasmids pKm1 and the DHFR- CHO cells, Dr. D. Baltimore for the plasmid pYJ1, Dr. M. Hatanaka for the plasmid pATLV421, Dr. M. Yoshida for the phage lambda Y7311A, Dr. L.W. Enquist for the plasmid pTK, Dr. K. Kumagai for the NKC3 cells, Dr. Y. Okada for the mouse $\mathrm{TK}^{-} \mathrm{L}$ cells, Drs. O. Shiho, S. Hinuma and M. Koyama for performing the IL-2 assays, and Dr. M. Dickmann for detailed information on DNA transfection and cell culture.

\section{REFERENCES}

1. Beck, E., G. Ludwig, B. Reiss and H. Schafler. Nucleotide sequence and exact localization of the neomycin phosphotransferase gene from transposon Tn5. Gene. 19, 327-336, 1982

2. Blin, N. and D.W. Stafford. A general method for isolation of high molecular weight DNA from eukaryotes. Nucleic Acids Res. 3, 2303-2308, 1976 
3. BRoOKS, C. and C.S. HeNNEY. Interleukin-2 and the regulation of natural killer activity in cultured cell populations. In Contemporary Topics in Molecular Immunology, 10, S. Gillis and F.P. Inman, eds. (Plenum, New York) pp. 63-92, 1985

4. Colbere-Garapin, F., F. Horodniceanu, P. Kourilsky and A.C. Garapin. A new dominant hybrid selective marker for higher eukaryotic cells. J. Mol. Biol. 150, 1-14, 1981

5. Conradt, H.S., M. Ausmeier, K.E.J. Dittmar, H. Hauser and W. Lindenmaier. Secretion of glycosylated human interleukin-2 by recombinant mammalian cell lines. Carbohydrate Res. 149, 443-450, 1986

6. Enquist, L.W., G.F. Van De Woude, M. Wagner, J.R. Smiley and W.C. Summers. Construction and characterization of a recombinant plasmid encoding the gene for the thymidine kinase of herpes simplex type 1 virus. Gene. 7, 335-342, 1979

7. Gluzman, Y. Ed. Eukaryotic Viral Vectors. (Cold Spring Harbor Laboratory, Cold Spring Harbor, New York.), 1982

8. Goff, S.P., E. Gilboa, O.N. Witte and D. Baltimore. Structure of the Abelson murine leukemia virus genome and the homologous cellular gene: studies with cloned viral DNA. Cell 22, 777-785, 1980

9. Gorman, C.M., G.T. Merlino, M.C. Willingham, I. Pastan and B.H. Howard. The Rous sarcoma virus long terminal repeat is a strong promoter when introduced into a variety of eukaryotic cells by DNA-mediated transfection. Proc. Natl. Acad. Sci. USA 79, 6777-6781, 1982

10. Gorman, C.M., R. Padmanabhan and B.H. Howard. High efficiency DNA-mediated transfection of primate cells. Science 221, 551-553, 1983

11. Hanahan, D. Studies on transformation of Escherichia coli with plasmids. J. Mol. Biol. 166, $557-580,1983$

12. Haynes, S. and C. Weissman. Constitutive, long-term production of human interferons by hamster cells containing multiple copies of a cloned interferon gene. Nucleic Acids Res. 11, $687-705,1983$

13. Hinuma, S., H. Onda, K. Naruo, Y. Ichimori, M. Koyama and K. Tsukamoto. Translation of interleukin 2 mRNA from human peripheral blood leukocytes in Xenopus oocytes. Biochem.

Biophys. Res. Comm. 109, 363-369, 1982

14. Joyner, A., Y. Yamamoto and A. Bernstein. Retrovirus long terminal repeats activate expression of coding sequence for the herpes simplex virus thymidine kinase gene. Proc. Natl. Acad. Sci. USA 79, 1573-1577, 1982

15. Kato, K., K. Naruo, M. Koyama, K. Kawahara, S. Hinuma, H. Tada, H. Sugino and K. Tsuкамото. Purification and partial sequence analysis of human interluekin-2 derived from peripheral blood leukocytes. Biochem. Biophys. Res. Commun. 127, 182-190, 1985

16. Kaufman, R.J. and P.A. Sharp. Amplification and expression of sequences cotransfected with a modular dihydrofolate reductase complementary DNA gene. J. Mol. Biol. 159, 601-621, 1982

17. KESSLER, S.W. Rapid isolation of antigens from cells with a staphylococcal protein A-antibody adsorbent: parameters of the interaction of antibody-antigen. J. Immunol. 115, 1617-1624, 1975

18. Khouly, G. and P. Gruss. Enhancer elements. Cell 33, 313-314, 1983

19. K. Toyoshima, Y. Hirayama and M. Yoshida. Avian sarcoma virus Y73 genome sequence and structural similarity of its transforming gene product to that Rous sarcoma virus. Nature 297, 205-208, 1982

20. Kobayashi, N., N. Yamamoto, Y. Koyanagi, J. Shneider, G. Hunsmann and M. Hatanaka. Translation of HTLV (human T-cell leukemia virus) RNA in a nuclease-treated rabbit reticulocyte system. EMBO J. 3, 321-325, 1984

21. LaemmLi, U.K. Cleavage of structural proteins during the assembly of the head of bacteriophage T4. Nature 227, 680-685, 1971

22. Laimins, L.A., G. Khoury, C. Gorman, B. Howard and P. Gruss. Host specific activation of transcription by tandem repeats from simian virus 40 and Moloney murine sarcoma virus. Proc. Natl. Acad. Sci. USA 79, 6453-6457, 1982 
23. Littlefield, J.W. Selection of hybrids from matings of fibroblasts in vitro and their presumed recombinants. Science 145, 709-710, 1964

24. Maniatis, T., E.F. Fritsh and J. Sambrook. Molecular Cloning: A Laboratory Manual. (Cold Spring Harbor Laboratory, Cold Spring Harbor, New York), 1982

25. Michel, M.L., E. Sobczak, Y. Malpiece, P. Ttollais and R.E. Streek. Expression of amplified hepatitis B virus surface antigen genes in chinese hamster ovary cells. Biotechnology 3, 561-566, 1985

26. Naruo, K., S. Hinuma, K. Kato, M. Koyama, H. Tada, O. Shiho and K. Tsukamoto. Comparison of the biological properties of the purified natural and recombinant human interleukin-2. Biochem. Biophys. Res. Commun. 128, 257-264, 1985

27. OKayama, H. and P. Berg. A cDNA cloning vector that permits expression of cDNA inserts in mammalian cells. Mol. Cell. Biol. 3, 280-289, 1983

28. Paetkau, V., R.C. Bleakey, D. Riendeau, D.G. Harnish and E.W. Holowachuk. Toward the molecular biology of IL-2. In Contemporary Topics in Molecular Immunology 10, S. Gillis and F.P. Inman, eds. (Plenum, New York) pp. 35-61, 1985

29. Rigby, P.W.J., M. Dieckmann, C. Rhodes and P. Berg. Labeling deoxyribonucleic acid to high specific activity in vitro by nick translation with DNA polymerase I. J. Mol. Biol. 113, 237-251, 1977

30. Rosenberg, S.A., E.A. Grimm, M. McGrogan, M. Doyle, E. Kawasaki, K. Koths and D.F. MARK. Biological activity of recombinant human interleukin-2 produced in Escherichia coli. Science 223, 1412-1414, 1984

31. Sснimke, R.T. Gene amplification in cultured animal cells. Cell 37, 705-713, 1984

32. Seno, M., S. Hinuma, H. Onda and K. Igarashi. A hybrid protein between IFN- and IL-2. FEBS Lett. 199, 187-192, 1986

33. Sodroski, J.G., C.A. Rosen and W.A. Haseltine. Trans-acting transcriptional activation of the long-terminal repeat of human T lymphotropic viruses infected cells. Science 225, 381385,1984

34. Suzuki, R., K. Handa, K. Itoh and K. Kumagai. Natural killer (NK) cells as a responder to interleukin 2 (IL-2): I. Proliferative response and establishment of cloned cells. J. Immunol. 130, 981-987, 1983

35. Tada, H., O. Shino, M. Kuroshima and K. Tsukamoto. An improved colorimetric assay for interleukin-2. J. Immunol. Methods 93, 157-165, 1986

36. Urlaub, G. and L.A. Chasin. Isolation of Chinese hamster cell mutants deficient in dihydrofolate reductase activity. Proc. Natl. Acad. Sci. USA 77, 4216-4220, 1980

37. Wahl, G.M., M. Stern and G.R. STARK. Efficient transfer of large DNA fragments from agarose gels to diazobenzyloxymethyl-paper and rapid hybridization by using dextran sulfate. Proc. Natl. Acad. Sci. USA 76, 3683-3689, 1979

38. Wigler, M., R. Sweet, G.K. Sim, B. Wold, A. Pellicer, E. Lacy, T. Maniatis, S. SilversteIn and R. Axel. Transformation of mammalian cells with genes from prokaryotes and eukaryotes. Cell 16, 777-785, 1979 